\title{
Midline-triangular liver presenting with extrahepatic porto-vena cava communication
}

\author{
PRYAKHIN, A. ${ }^{1}$, MCHONDE, G. ${ }^{2}$ and GESASE, A. P. ${ }^{1}$ \\ ${ }^{1}$ Department of Biomedical Sciences, School of Medicine, College of Health and Allied Sciences, \\ University of Dodoma, P.O. Box 259, Dodoma, Tanzania \\ ${ }^{2}$ Department of Cell Biology and Neuroanatomy, School of Medicine, Iwate Medical University, \\ 2-1-1 Nishi-Tokuda, Yahaba-cho, Shiwa-gun, 028-3694, Iwate, Japan \\ *E-mail: alpryakhin1980@gmail.com
}

\begin{abstract}
The current observation has documented a 50 years old male cadaver with anomalous triangular liver that was situated in the midline of the abdomen, occupying the epigastrium, umbilical and the suprapubic regions and pushing the small intestines into the pelvic cavity. The triangular liver contained two separate right and left portions that were attached by the peritoneal folds to the anterior abdominal wall, xiphoid process and lower costal cartilages. The left liver portion received a direct arterial supply from the aorta. The portal vein gave rise into two extrahepatic tributaries that opened directly into the inferior vena cava. Other anomalies that were observed in the abdomen included the oval-shaped stomach located in the left abdomen and extending into the left lumbar region. The transverse colon was situated in the suprapubic region and small intestines occupied the suprapubic region and the pelvic cavity. The right testicular vein drained into the right renal vein. The current observations report for the first time midline triangular liver occurring with extrahepatic porto-vena cava communication. The origin of the anomalies of hepatic morphology occurring in the course of organogenesis remains to be determined. Continued documentation of liver anomalies remains to be important in medical practice and in the understanding of liver ontogeny.
\end{abstract}

Keywords: liver, porta hepatis, inferior vena cava, ventral mesogastrium, congenital anomalies.

\section{Introduction}

Congenital anomalies that occur in the liver alone are considered to be rare and the frequency increases when other organs become involved (CHAMPETIER, YVER, LETOUBLON et al., 1985). At autopsy situations the frequency is low and some authors have suggested that liver anomalies are best found at laparoscopy (SATO, WATANABE, NAGASAWA et al., 1998). The documented anomalies of the liver include right hepatic lobeagenesis (RADIN, COLLETTI, RALLS et al., 1987; GATHWALA and SEN, 2003; IANNELLI, FACCHIANO, FABIANI et al., 2005; JIMÉNEZ FUERTES, LÓPEZ ANDÚJAR, LLORET LARREA et al., 2007; SUH, KIM, KIM et al., 2008); ectopic liver (BEDII SALMAN, 2002; KOH and HUNT, 2007; CHALAK and PARHAM, 2007); supernumerary liver (CHARBONNEL, VAN KOTE, GODEFFROY et al., 1988; D'AGOSTINO, MUSI, DANTE et al., 1989); accessory liver (IKOMA, TANAKA, HAMADA et al., 1992; KASZNICA, VAN PRAAGH and PHILIP, 1997; ITO, ANDO, WATANABE et al., 1999; BEILER, SERGI, WAGNER et al., 2001); hypogenesis of the right hepatic lobe (INOUE, ITO, MATSUZAKI et al., 1997); bifid liver (DAVER, BAKHSHI, PATIL et al., 2005); vascular anomalies (SERRIEN, RIGAUTS, MARCHAL et al., 1992; KOHDA, SAEKI, NAKANO et al., 1999; GALLEGO, MIRALLES, MARÍN et al., 2004); agenesis of the left hepatic lobe (FOGH, TROMHOLT and JORGENSEN, 1989); hypoplasia of the left hepatic lobe (SAIGUSA, AOKI and HORIGUCHI, 2001; LEE, MURAKAMI and HAM, 2004); accessory hepatic fissure and sulci (AUH, RUBENSTEIN, ZIRINSKY et al., 1984; MACCHI, FELTRIN, PARENTI et al., 2003) andleft-sided liver (SACKS and RIFKIN, 1987). Positional anomalies of the liver have also been documented in cases of situs inversus (ION and TIBERIU, 1982; ENGELBERG, JEDEIKIN, ZAGER et al., 1978; PATHAK, KHANNA and KHANNA, 1995; MARTA, FALCAO, SAAVEDRA et al., 2003). Other developmental anomalies include lobulated liver (VENDELAND and SHEHADEH, 2000; CHUNG, CHOI, PARK et al., 2001); inverted liver (HIBBS and AHMAD, 2010) and midline small liver (KOO and CHI, 1991). Continued documentation of liver anomalies remains to be important both anatomically and clinically. Some of anomalies have been shown to lead into liver pathology; for example, presence of accessory lobe may stimulate the development of tumor or may lead to abdominal mass that may lead to misdiagnosis (IKOMA, TANAKA, HAMADA et al., 1992). Observations have also showed that suprahepatic gallbladder is commonly associated with agenesis or hypogenesis of the right lobe of the liver and patients with this anomaly are likely to develop pathology of the gallbladder (FAINTUCH, MACHADO and RAIA, 1980; IKOMA, TANAKA, HAMADA et al., 1992; SHEU, LIN, CHEN et al., 1995). Defective development of the left lobe of the liver can lead to gastric volvulus (CHAMPETIER, YVER, LETOUBLON et al., 1985).

\section{Case Report}

The anomalous liver was observed in a 50 years old male cadaver during dissection. The anomalous liver was the most anterior structure in the upper abdomen and extendings lightly into the left abdomen (Figure la). It occupied mainly the 


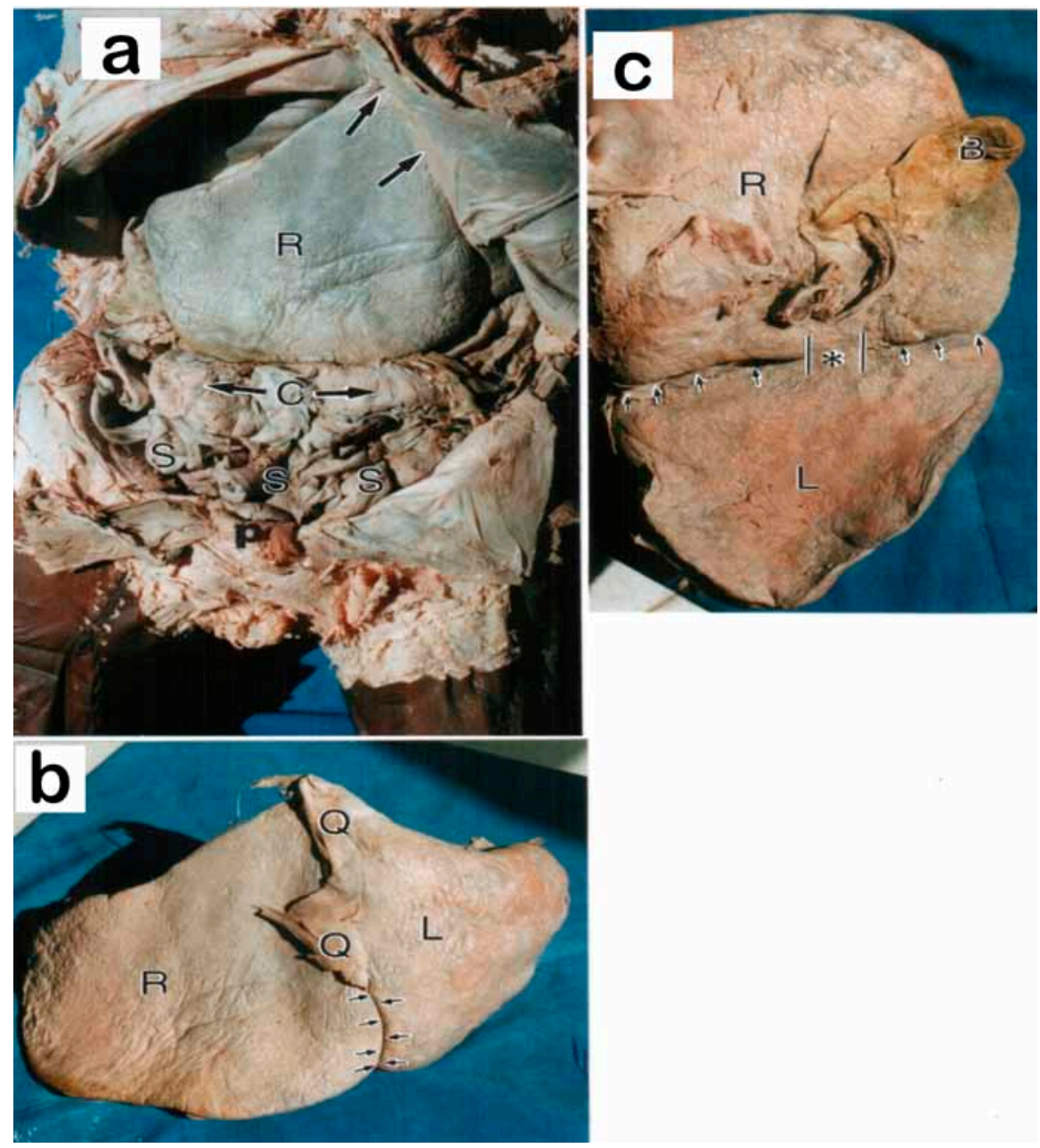

Figure 1. (a) The photograph of a 50 year old male cadaver showing the right portion $(\boldsymbol{R})$ of the anomalous triangular midline liver attached to the anterior abdominal wall via the peritoneal fold $(\boldsymbol{A r r o w s})$. Note the pubic symphysis $(\boldsymbol{P})$ and the transverse colon $(\boldsymbol{C})$ in the suprapubic region; the small intestines $(S)$ extend into the pelvic cavity; (b) The anterior surface of the anomalous triangular liver shows the right $(\boldsymbol{R})$ and left $(\boldsymbol{L})$ portions, vertical cleft (Small arrows) and peritoneal folds in the vertical cleft $(\boldsymbol{Q}) ;(\mathrm{c})$ The anomalous liver showing the right $(\boldsymbol{R})$ and left $(\boldsymbol{L})$ portions separated by a cleft (Small arrows). Opposite the porta hepatis there is a narrow band of hepatic tissue that connects the two louver portions. Note the position of the gallbladder $(\boldsymbol{B})$.

epigastrium, umbilical regions and inferiorly the anomalous liver extended into the suprapubic region, and pushing the transverse colon into the suprapubic regionand the small intestines into the pelvic cavity. Its left border extended into left hypochondrium and left lumbar to cover the left kidney. On the right side it extended for about $5 \mathrm{~cm}$ into the right hypochondriac region. The liver appeared to be triangular in shape with the apex attached to the xiphoid process and its base reaching the suprapubic region. The anomalous liver measured $25 \mathrm{~cm}$ long i.e. transversely from the right to the left and $16 \mathrm{~cm}$ long from the apex to the base. The base of the liver was free and not attached into the abdominal organs. For the purpose of this observation the anomalous liver was described to have the anterior and posterior surfaces and the right and left borders.

\subsection{Anterior surface}

The anterior surface showed the vertical cleft that divided the liver into two right and left portions which were easily separated upon retraction (Figure la and $\mathrm{lb}$ ). Upon inserting a probe it was revealed that the cleft was obliquely oriented. The cleft measured $16 \mathrm{~cm}$ long and in the upper $2 / 3$ it contained the peritoneal fold that appeared to attach the liver to the anterior abdominal wall. At the apex of the anomalous liver the peritoneal fold was thicker and appeared suspending the anomalous liver to the xiphoid process and adjacent costal cartilages and the rectus abdominis muscle. The cleft was clearly seen on the lower $1 / 3$ of the liver and it did not contain the peritoneum (Figure $1 \mathrm{~b}$ ). The right portion of the anomalous liver was slightly larger $(9 \mathrm{~cm}$ long and $15 \mathrm{~cm}$ wide $)$ than the left portion which measured about $7 \mathrm{~cm}$ long and $10 \mathrm{~cm}$ wide (Figure $1 \mathrm{~b}$ ). Its right border corresponded with an imaginary vertical line drawn from the tip of the $9^{\text {th }}$ costal cartilage and the left border contained the peritoneal fold, which separated it from the right border of the left portion of the anomalous liver. A small peritoneal attachment measuring about $2.5 \mathrm{~cm}$ wide was seen on the right border of the right portion of the anomalous liver and it appeared to attach to the anterior abdominal wall. 
The left portion of the anomalous liver was seen after retracting the anterior abdominal wall to the left. It appeared also to be triangular in shape and was separated from the right portion by a cleft. Its left border extended to reach the imaginary vertical line drawn through the $11^{\text {th }}$ rib and the left kidney was completely covered by the left portion of the anomalous liver. The left portion of the anomalous liver received a direct arterial branch from the abdominal aorta. Artery was seen to arise from the anterior surface of the aorta superior to the right suprarenal artery. The left portion also contained what appeared to be the left hepatic vein that pierced the diaphragm to enter the thorax where it opened into the inferior vena cava (Figure 2b).

The peritoneal fold which was considered to be an atypical falciform ligament; at the beginning it was broad measuring about $11 \mathrm{~cm}$ wide and becoming narrow as it ascended upwards. Upon reaching the apex of the anomalous liver it became thicker and attached the liver firmly into the xiphoid process, diaphragm and left rectus abdominis muscles (Figure la and lb). The base of the anomalous liver, which formed the inferior surface, was well delineated and a small part of the gallbladder was seen protruding at about $1.5 \mathrm{~cm}$ below the umbilicus.

\subsection{Posterior surface}

The posterior surface of the anomalous liver was facing the posterior abdominal wall and it was related with the stomach, duodenum, proximal jejunum and pancreas. Close examination revealed the presence of a short and broad peritoneal fold that fixed the anomalous liver to the posterior abdominal wall and enclosing also the porta hepatis and the inferior vena cava (Figure 2). The porta hepatis was located on the right portion of the liver and it contained part of the portal vein, lymphatic vessels, bile duct and nerves. At about $2 \mathrm{~cm}$ inferior to the portal hepatis, the portal vein appeared to give rise into two tributaries; from the right and left border (Figure 2a). The portal tributary from the right border appeared larger measuring about $1.5 \mathrm{~cm}$ long and $1 \mathrm{~cm}$ wide and it terminated by entering the right border of the inferior vena cava. The left portal tributary appeared smaller but took a longer course; it penetrated the liver substance to open into the left border of the inferior vena cava. The two right and left portal vein tributaries appeared to allow extrahepatic communication between the portal vein and the inferior vena cava. Examination of the inferior vena cava revealed some anomalous features; the inferior vena cava occupied the fissure between the right and left portions and here it received the right hepatic vein (Figure 2b). The left hepatic vein showed a different course, it measured about $2 \mathrm{~cm}$ long and after emerging from the left portion it pierced the left hemidiaphragm to enter the thorax where it opened into the inferior vena cava. The opening was on the left side of the inferior vena cava.

After examining the porta hepatis the liver was removed from the abdomen in order to observe the extent and anatomy of the cleft on the posterior surface of the anomalous liver. The deep cleft observed on the anterior surface extended into the posterior surface separating completely the two right and left portions of the anomalous liver. Close observation revealed the existence of a narrow band of hepatic tissue that appeared to connect the right and left portions of the anomalous liver. The band was thin measuring about $0.25 \mathrm{~cm}$ thick and it appeared to contain the hepatic substance.
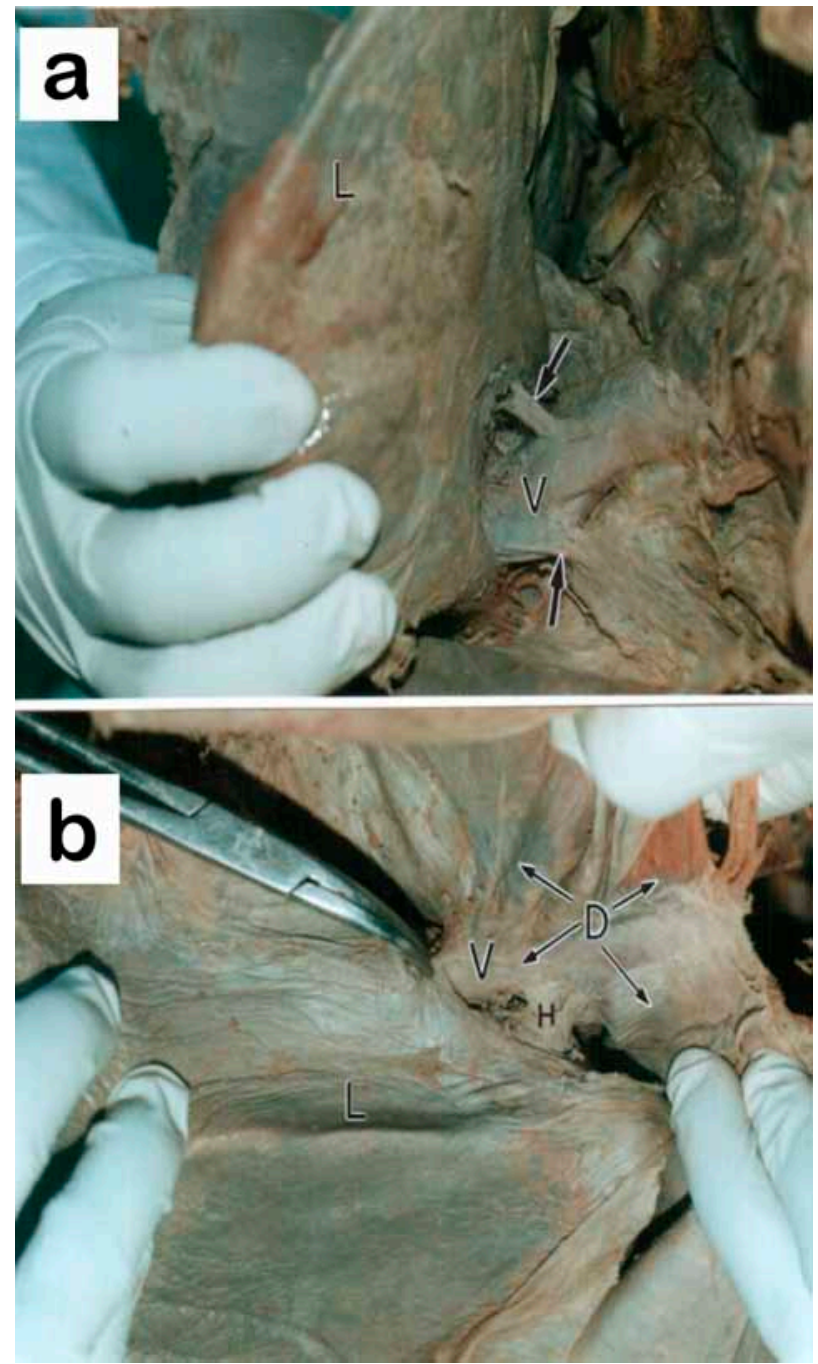

Figure 2. (a) The inferior vena cava ( $\boldsymbol{V})$ receives two tributaries (Arrows) from the portal vein before it enters the liver substance; (b) The inferior vena cava $(\boldsymbol{V})$ and the left hepatic vein from the left portion of the anomalous liver piercing the diaphragm $(\boldsymbol{D})$; the left hepatic vein $(\boldsymbol{H})$ enters the inferior vena cava after entering the thorax.

\subsection{Other associated visceral anomalies}

The pericardium was adherent to the thoracic opening of the inferior vena cava and was not attached to the diaphragm. The right dome of the diaphragm appeared concave in the thoracic side and convex in the abdomen; the concavity was occupied by the normal looking right lung. The stomach occupied the left hypochondriac region, extending into the left lumbar region. It was ovoid in shape and did not show the presence of lesser and grater curvature. The transverse colon was found on the lower part of the suprapubic region and the small intestines were located in the suprapubic region and in the pelvic cavity. Other associated anomalies involved the testicular veins; the right testicular vein drained into the right renal vein and the left testicular vein opened into the left renal vein. Other organs appeared normal and the heart, spleen and the vermiform appendix occupied their normal position. 


\section{Discussion}

The current observation has documented a 50 years old male cadaver with anomalous triangular liver that was situated mainly in the midline of the abdomen, occupying the epigastrium, umbilical and the suprapubic regions and pushing the small intestines into the pelvic cavity. The triangular liver contained two separate right and left portions that were attached to the anterior abdominal wall, xiphoid process and lower costal cartilages by the peritoneal fold. The left liver portion received a direct arterial supply from the aorta and the portal vein gave rise into two tributaries that opened into the inferior vena cava. The associated extrahepatic anomalies include the oval-shaped stomach located in the left abdomen and extending into the left lumbar region. The small intestines were located in the pelvic cavity and the right testicular vein drained into the right renal vein. The current observations report for the first time midline triangular liver occurring with extrahepatic porto-vena cava communication. Continued documentation of liver anomalies remains to be important in medical practice and in the understanding of liver ontogeny.

In normal anatomy the liver is located on the right side of the upper abdomen and its greater part is in contact with the left hemidiaphragm. In the current observation the liver was located in the midline of the body and was not in contact with the diaphragm. Triangular-shaped liver occurring in the midline of an adult person is a new finding and has not been reported before. Review of literature have showed that there is only one documented case of midline liver, in this observation the liver was found to be small and it co-existed with congenital hydrocephalus (KOO and CHI, 1991). Positional anomalies of the liver are very rare; the documented cases of left-sided liver have been commonly seen in association with situs inversus and Kartagener's syndrome (ENGELBERG, JEDEIKIN, ZAGER et al., 1978; MARTA, FALCAO, SAAVEDRA et al., 2003). In one case the left sided liver was associated with mirror image arrangement of other abdominal organs (SACKS and RIFKIN, 1987). Midline liver is a form of positional anomalies of the liver and its exact frequency need to be determined. Liver anomalies are mostly reported following radiological investigation and endoscopic examination of the abdomen. It is possible that we may be missing some of liver anomalies because of lack of investigation (CHAMPETIER, YVER, LETOUBLON et al., 1985). In Africa imaging methods such as CT scan and ultrasound are not available and autopsy is seldom done. At present there is no clear explanation as to why the liver was located in the midline. During embryonic development the liver develops in the midline from a single hepatic diverticulum that grows to invade the septum transversum (SADLER, 2010). Septum transversum is quite extensive and it occupies the midline, ventral and dorsal parts of the embryo (COLLINS, 2002). It is possible that in the current case liver remained in the midline and did not grow into the right abdomen. Future work needs to be done on pathways that regulate liver development and mechanisms that regulate migration from the midline to the right abdomen.

The anomalous triangular liver contained two, right and left liver portions that were largely separated except for a small middle band that that appeared to unite the two portions. Normally the liver occurs as a single organ and presence of two separate portions has not been reported before. The possible explanation for this observation can be derived from the current findings; the cleft that separated the two liver portions contained the peritoneal folds. Posteriorly the peritoneal folds appeared to attach the liver to the posterior abdominal wall and ventrally the peritoneum entered the cleft and attaching the two liver portions to the anterior abdominal wall. During development the liver is associated with the ventral mesogastrium, which split to enclose the liver and anteriorly it forms the falciform ligament that attach the liver to the anterior abdominal wall (MOORE and DALLEY, 1999). It is possible that in the current report the ventral mesogastrium took a different course whereby it passed through the developing liver to make a cleft that separated the right and left liver portions. It is interesting to note that the left liver portion received its arterial branch directly from the abdominal aorta and its hepatic vein pierced the diaphragm pierced the diaphragm to enter the thorax before draining into the inferior vena cava. In normal anatomy the inferior vena cava receive hepatic veins before it pierces the diaphragm. Hepatic veins have not been adequately studied and yet they are clinically important; occlusion of hepatic vein can lead to severe liver pathology and death. The current observations provide a challenge for future detailed study on liver development.

The current report has also showed the presence of extrahepatic communication between the tributaries of the portal vein and the inferior vena cava. In normal anatomy the portal vein does not communicate with the inferior vena cava, instead it enters the liver and branch into smaller tributaries that pour blood into the hepatic sinusoids (MOORE and DALLEY, 1999). Observations indicated that the portal vein before entering the liver substance gave rise into two tributaries that joined the inferior vena cava. Congenital portosystemic venous shunts are rare; past studies have showed the presence of two intrahepatic and extrahepatic portosystemic venous shunts (MULLIKEN and GLOWACKI, 1982; PARK, CHA, HAN et al., 1990; LIN, CHEN, HSIEH et al., 2006; STRINGER, 2008). Extrahepatic shunts also known as Abernethy malformations occur outside the liver before the portal vein enters the liver substance and two types 1 and 2 have been suggested (MORGAN and SUPERINA, 1994). In type 1 , the portal vein is absent and as a result portal blood is shunted directly to the inferior vena cava. In type 2 , the portal vein is intact, but some of the portal blood is diverted into the inferior vena cava through an extrahepatic communication (MORGAN and SUPERINA, 1994; STRINGER, 2008). The current observation showed the presence of type 2 , whereby the portal vein gave rise into two tributaries that entered the inferior vena cava. It has been suggested that the key to understanding the pathogenesis of these shunts lies in the normal developmental mechanisms underlying the formation of the portal vein and inferior vena cava in the embryo (STRINGER, 2008). The terminal part of the inferior vena cava, the hepatic veins and the portal vein develop from the vitelline vein; the vitelline also develop to form the hepatic sinusoids (MOORE, 1977). The fact that development of inferior vena cava is closely associated with the vitelline veins which also give rise to the porta vein may explain the occurrence of communication between the portal vein and inferior vena cava seen in the current report. Portosystemic shunting is clinically important and is associated with metabolic pathology such as hypergalactosemia, lack of nutrients and increased bile acid, postprandial glucose and ammonia blood levels (WAKAMOTO, MANABE, KOBAYASHI et al., 1999; AKAHOSHI, NISHIZAKI, WAKASUGI et al., 2000; 
MAEKAWA, SUZUKI, MORI et al., 2007), tumor and nodular hyperplasia (MOTOORI, SHINOZAKI, GOTO et al., 1997; DE GAETANO, GUI, MACIS et al., 2004). Lack of nutrients in the liver may lead to fatty degeneration and atrophy leading to dysfunction (ALTAVILLA and CUSATELLI, 1998; ARANA, MARTI-BONMATI, MARTINEZ et al., 1997). Systemic diversion of portal blood flow may interfere with liver functions and regenerative capacity leading to liver tumor (MOTOORI, SHINOZAKI, GOTO et al., 1997; ALTAVILLA and CUSATELLI, 1998; GRAZIOLI, ALBERTI, OLIVETTI et al., 2000).

The current report has documented the co-existence of liver anomalies with extra-hepatic congenital anomalies. Development of the liver is closely related to embryonic structures including the precardiac mesenchyme, septum transversum, vitelline veins, diaphragm, ventral mesogastrium and the caudal parts of the primitive foregut. How these structures interact during development to give into normal liver morphology is not clearly known. Continued documentation of liver anomalies and research on molecular pathways that regulate liver ontogeny remains to be anatomically and clinically important.

Acknowledgements: We wish to thank Selemani Shomvi and Hamisi Rajabu for their excellent technical support.

\section{References}

AKAHOSHI, T., NISHIZAKI, T., WAKASUGI, K., MASTUZAKA, T., KUME, K., YAMAMOTO, I. and SUGIMACHI, K. Portal-systemic encephalopathy due to a congenital extrahepatic portosystemic shunt: three cases and literature review. Hepato-Gastroenterology, 2000, vol. 47, n. 34, p. 1113-1116. PMid:11020891.

ALTAVILLA, G. and CUSATELLI, P. Ultrastructural analysis of the liver with portal vein agenesis: a case report. Ultrastructural Pathology, 1998, vol. 22, n. 6, p. 477-483. PMid:9891927.

ARANA, E., MARTI-BONMATI, L., MARTINEZ, V., HOYOS, $M$. and MONTES, H. Portal vein absence and nodular regenerative hyperplasia of the liver with giant inferior mesenteric vein. Abdominal Imaging, 1997, vol. 22, n. 5, p. 506-508. PMid:9233888.

AUH, YH., RUBENSTEIN, WA., ZIRINSKY, K., KNEELAND, JB., PARDES, JC., ENGEL, IA., WHALEN, JP. and KAZAM, E. Accessory fissure of the liver: CT and sonographic appearance. American Journal of Roentgenology, 1984, vol. 143, n. 3, p. 565-572. PMid:6331736.

BEDII SALMAN, A. Left-sided congenital diaphragmatic hernis associated with intrathoracic ectopic liver lobule. European Journal of CardioThoracic Surgery, 2002, vol. 21, n. 3, p. 558-560. PMid:11888785.

BEILER, HA., SERGI, C., WAGNER, G. and ZACHARIOU, Z. Accessory liver in an infant with congenital diaphragmatic hernia. Journal of Pediatric Surgery, 2001, vol. 36, n. 6, p. 1-3. http:// dx.doi.org/10.1053/jpsu.2001.24020. PMid:11381450.

CHALAK, LF. and PARHAM, DM. A newborn with Poland anomaly and liver ectopy: an unusual association with important prognostic implications. Pediatric and Developmental Pathology, 2007, vol. 10, n. 2, p. 134-137. PMid:17378683.

CHAMPETIER, J., YVER, R., LETOUBLON, C. and VIGNEAU, B. A general review of anomalies of hepatic morphology and their clinical implications. Anatomia Clinica, 1985, vol. 7, n. 4, p. 285299. PMid:3833290.

CHARBONNEL, E., VAN KOTE, G., GODEFFROY, Y., DREUXBOUCARD, H., MENGUY, M. and LECONTE, D. Supernumerary liver: a case with a particular location in an omphalocele. Chirurgie Pediatrique, 1988, vol. 29, n. 6, p. 330-335. PMid:3067885.
CHUNG, JL., CHOI, JR., PARK, MS. and CHOI, SH. A case of $\operatorname{del}(13)(\mathrm{q} 22)$ with multiple major congenital anomalies, imperforate anus and penoscrotal transposition. Yonsei Medical Journal, 2001, vol. 42 , n. 5, p. 558-562. PMid:11675686.

COLLINS, P. Embryology of the liver and bile ducts. In HOWARD, ER., STRINGER, MD. and COLOMBANI, PM. (Eds.). Surgery of the liver, bile ducts and pancreas in children: part 3. London: Arnold, 2002. 576 p.

D’Agostino, S., MUSi, L., DANTE, S. and BELlOLI, G. Supernumerary liver localized in the navel: description of a case. La Pediatria Medica e Chirurgica, 1989, vol. 11, n. 4, p. 451-453. PMid:2616349.

DAVER, GB., BAKHSHI, GD., PATIL, A., ELLUR, S., JAIN, M. and DAVER, NG. Bifid liver in a patient with diaphragmatic hernia. Indian Journal of Gastroenterology, 2005, vol. 24, n. 1, p. 27-28. PMid:15778526.

DE GAETANO, AM., GUI, B., MACIS, G., MANFREDI, R. and DI STASI, C. Congenital absence of the portal vein associated with focal nodular hyperplasia in the liver in an adult woman: imaging and review of literature. Imaging, 2004, vol. 29, n. 4, p. 455-459. PMid:14716452.

ENGELBERG, M., JEDEIKIN, RK., ZAGER, M., HOFFMAN, S. and REISS, R. Traumatic rupture of a left-sided liver and postoperative acute respiratory failure in a patient with Kartageners's syndrome. The Journal of Trauma, 1978, vol. 18, n. 7, p. 545-547. PMid:307608.

FAINTUCH, J., MACHADO, MC. and RAIA, AA. Sprahepatic gallbladder with hypoplasia of the right lobe of the liver. Archives of Surgery, 1980, vol. 115, n. 5, p. 658-659. PMid:7377967.

FOGH, J., TROMHOLT, N. and JORGENSEN, F. Persistent impairment of liver function caused by a pendulated accessory liver lobe. European Journal of Nuclear Medicine, 1989, vol. 15, n. 6, p. 326-327. http://dx.doi.org/10.1007/BF00435474. PMid:2767082.

Gallego, C., Miralles, M., MARíN, C., MUYOR, P., GONZÁLEZ, G. and GARCÍA-HIDALGO, E. Congenital hepatic shunts. Radiographics, 2004, vol. 24, n. 3, p. 755-772. http://dx.doi. org/10.1148/rg.243035046. PMid:15143226.

GATHWALA, G. and SEN, J. Agenesis of the right lobe of liver. Indian Journal of Pediatrics, 2003, vol. 70, n. 2, p. 183-184. PMid:12661818.

GRAZIOLI, L., ALBERTI, D., OLIVETTI, L., RIGAMONTI, W., CODAZZI, F., MATRICARDI, L., FUGAZZOLA, C. and CHIESA, A. Congenital absence of portal vein with nodular regenerative hyperplasia of the liver. European Radiology, 2000, vol. 10, n. 5, p. 820-825. PMid:10823641.

HIBBS, H. and AHMAD, U. Inverted liver with suprahepatic, anteriorly displaced gallbladder. The Journal of the Louisiana State Medical Society, 2010, vol. 162, n. 3, p. 150-152. PMid:20666167.

IANNELLI, A., FACCHIANO, E., FABIANI, P., SEJOR, E., BERNARD, JL., NIEZAR, E. and GUGENHEIM, J. Agenesis of the right liver: a difficult laparascopic cholecystectomy. Journal of Laparoendoscopic \& Advanced Surgical Techniques. Part A., 2005, vol. 15, n. 2, p. 166-169. PMid:15898910.

IKOMA, A., TANAKA, K., HAMADA, N., HONBO, K., YAMAUCHI, T., ISHIZAKI, N., TAIRA, A. and MUKAI, M. Left-sided gallbladder with accessory liver accompanied by intrahepatic cholangiocarcinoma. Nippon Geka Gakkai Zasshi, 1992, vol. 93, n. 4, p. 434-436. PMid:1318496.

INOUE, T., ITO, Y., MATSUZAKI, Y., OKAUCHI, Y., KONDO, H., HORIUCHI, N., NAKAO, K. and IWATA, M. Hypogenesis of right hepatic lobe accompanied by portal hypertension: case report and review of 31 Japanese cases. Journal of Gastroenterology, 1997, vol. 32, n. 6, p. 836-842. http://dx.doi.org/10.1007/BF02936965. PMid:9430027. 
ION, A. and TIBERIU, CG. Anatomical features of liver in situs inversus. Acta Anatomica, 1982, vol. 112, n. 4, p. 353-364. PMid:7113639.

ITO, F., ANDO, H., WATANABE, Y., SEO, T., MURAHASHI, O., HARADA, T., KANEKO, K. and ISHIGURO, Y. An accessory lobe of the liver disturbing closure of the umbilical ring. Pediatric Surgery International, 1999, vol. 15, n. 5-6, p. 394-396. http:// dx.doi.org/10.1007/s003830050609. PMid:10415296.

JIMÉNEZ FUERTES, M., LÓPEZ ANDÚJAR, R., LLORET LARREA, M., MOYA HERRÁIZ, A. and MIR PALLARDÓ, J. Right hepatic lobe agenesis. Where is the gallbladder? Cirugia Espanola, 2007, vol. 82, n. 4, p. 238-240. PMid:17942051.

KASZNICA, J., VAN PRAAGH, R. and PHILIP, AT. Right-sided high origin of diaphragm associated with accessory lobe of liver, lobulated right atrial appendage, and ipsilateral phrenic nerve hamartoma: a case report. Pediatric Pathology \& Laboratory Medicine, 1997, vol. 17, n. 4, p. 653-662. http://dx.doi.org/10.1080/15513819709168744. PMid:9211560.

$\mathrm{KOH}, \mathrm{CE}$. and HUNT, R. Ectopic liver encountered during laparascopic cholecystectomy. Asian Journal of Surgery, 2007, vol. 30, n. 3, p. 227-229. PMid:17638645.

KOHDA, E., SAEKI, M., NAKANO, M., MASAKI, H., OGAWA, K., NIRASAWA, M. and HIRAMATSU, K. Congenital absence of the portal vein in a boy. Pediatric Radiology, 1999, vol. 29, n. 4, p. 235-237. PMid:10199899.

KOO, H. and CHI, JG. Congenital hydrocephalus-analysis of 49 cases. Journal of Korean Medical Science, 1991, vol. 6, n. 4, p. 287 298. PMid:1844637.

LEE, UY., MURAKAMI, G. and HAM, SH. Left lobe hypoplasia of the human liver: a report of two cases. Surgical and Radiologic Anatomy, 2004, vol. 26, n. 5, p. 417-423. PMid:15309531.

LIN, ZY., CHEN, SC., HSIEH, MY., WANG, CW., CHUANG, WL. and WANG, LY. Incidence and clinical significance of spontaneous intrahepatic portosystemic venous shunts detected by sonography in adults without potential cause. Journal of Clinical Ultrasound, 2006, vol. 34, n. 1, p. 22-26. PMid:16353230.

MACCHI, V., FELTRIN, G., PARENTI, A. and DE CARO, R. Diaphragmatic sulci and portal fissures. Journal of Anatomy, 2003, vol. 202, n. 3, p. 303-308. PMid:12713270.

MAEKAWA, S., SUZUKI, T., MORI, K., ICHII, O., KANDA, K., TAI, M., OCHIAI, H., EJIRI, Y., WAKATSUKI, S., TAKAGI, T., OHIRA, H., TASHIRO, M. and OTSUKI, M. Congenital absence of the portal vein in an adult woman with liver tumor. The Japanese Journal of Gastro-Enterology, 2007, vol. 104, n. 10, p. 1504-1511. PMid:17917399.

MARTA, MJ., FALCAO, LM., SAAVEDRA, JA. and RAVARA, L. A case of complete situs inversus. Revista Portuguesa de Cardiologia, 2003, vol. 22, n. 1, p. 91-104. PMid:12712813.

MOORE, KL. and DALLEY, AF. Clinically oriented anatomy. 4th ed. Philadelphia: Wolters Kluwer Lippincott Williams \& Wilkins, 1999. $1163 \mathrm{p}$.

MOORE, KL. The developing human: clinically oriented embryology. Philadelphia: W.B. Saunders Company, 1977. 411 p.

MORGAN, G. and SUPERINA, R. Congenital absence of the portal vein: two cases and a proposed classification system for portasystemic vascular anomalies. Journal of Pediatric Surgery, 1994, vol. 29, n. 9, p. 1239-1241. PMid:7807356.
MOTOORI, S., SHINOZAKI, M., GOTO, N. and KONDO, F. Case report: congenital absence of the portal vein associated with nodular hyperplasia in the liver. Journal of Gastroenterology and Hepatology, 1997, vol. 12, n. 9-10, p. 639-643. PMid:9407326.

MULLIKEN, JB. and GLOWACKI, J. Hemangiomas and vascular malformations in infants and children: a classification based on endothelial characteristics. Plastic and Reconstructive Surgery, 1982, vol. 69 , n. 3, p. 412-422. PMid:7063565.

PARK, JH., CHA, SH., HAN, JK. and HAN, MC. Intrahepatic portosystemic venous shunt. AJR. American Journal of Roentgenology, 1990, vol. 155, n. 3, p. 527-528. PMid:2117349.

PATHAK, KA., KHANNA, R. and KHANNA, NN. Situs inversus with cholelithiasis. Journal of Postgraduate Medicine, 1995, vol. 41, n. 2, p. 45-46. PMid:10707709.

RADIN, DR., COLLETTI, PM., RALLS, PW., BOSWELL JUNIOR, WD. and HALLS, JM. Agenesis of the right lobe of the liver. Radiology, 1987, vol. 164, n. 3, p. 639-642. PMid:3303118.

SACKS, LV. and RIFKIN, IR. Mirror image arrangement of the abdominal organs with a left-sided morphologically normal heart. British Heart Journal, 1987, vol. 58, n. 5, p. 534-536. PMid:3676045.

SADLER, TW. Langman's medical embryology. 11th ed. Philadelphia: Wolters Kluwer Lippincott Williams \& Wilkins, 2010. 385 p.

SAIGUSA, K., AOKI, Y. and HORIGUCHI, M. Hypoplasia of the left lobe of the liver. Surgical and Radiologic Anatomy, 2001, vol. 23, n. 5, p. 345-347. http://dx.doi.org/10.1007/s00276-001-0345-y. PMid:11824136.

SATO, S., WATANABE, M., NAGASAWA, S., NIIGAKI, M., SAKAI, S. and AKAGI, S. Laparoscopic observations of congenital anomalies of the liver. Gastrointestinal Endoscopy, 1998, vol. 47, n. 2, p. 136-140. http://dx.doi.org/10.1016/S0016-5107(98)70345-1. PMid:9512277.

SERRIEN, B., RIGAUTS, H., MARCHAL, G. and LAMBRECHTS, P. Congenital intrahepatic porto-systemic shunt. Journal Belge de Radiologie, 1992, vol. 75, n. 6, p. 492-494. PMid:1294580.

SHEU, BS., LIN, XZ., CHEN, CY., CHOW, NH., LIN, PW. and TSAI, HM. TSAI, HM. Suprahepatic gallbladder and right lobe anomaly of the liver in patients with biliary cancers. Digestive Diseases and Sciences, 1995, vol. 40, n. 11, p. 2411-2416. PMid:7587823.

STRINGER, MD. The clinical anatomy of congenital portosystemic venous shunts. Clinical Anatomy, 2008, vol. 21, n. 2, p. 147-157. http://dx.doi.org/10.1002/ca.20574. PMid:18161055.

SUH, HJ., KIM, WT., KIM, MY. and CHO, YK. CHO, YK. Combined anomaly of the right hepatic lobe agenesis and absence of the inferior vena cava: a case report. Korean Journal of Radiology, 2008, vol. 9, supplement, p. 61-64. PMid:18607129.

VENDELAND, LL. and SHEHADEH, L. Incidental finding of an accessory ovary in a 16-year-old at laparascopy.A case report. The Journal of Reproductive Medicine, 2000, vol. 45, n. 5, p. 435-438. PMid:10845180.

WAKAMOTO, H., MANABE, K., KOBAYASHI, H. and HAYASHI, M. Subclinical portal-systemic encephalopathy in a child with congenital absence of the portal vein. Brain \& Development, 1999, vol. 21, n. 6, p. 425-428. PMid:10487479.

Received June 21, 2015 Accepted July 7, 2016 